\title{
Traumatized Children in Hungary After World War II
}

\author{
Tuomas Laine-Frigren
}

\section{INTRODUCTION}

The aftermath of World War II in Europe saw huge numbers of orphaned and dislocated children. Having been separated from their homes and families to escape the horrors of war, ethnic cleansing and genocide, they caught the attention of many around the world and concerns were raised about their mental health, and how they would readjust to postwar realities. Across these devastated European landscapes, psychologists, social workers and journalists encountered children who were at once physically fragile yet disturbingly unchildlike at the same time- "little old men and women," trying to learn how to play and go to school again after their

\footnotetext{
T. Laine-Frigren $(\bowtie)$

Academy of Finland Centre of Excellence in the History of Experiences, Tampere University, Tampere, Finland e-mail: tuomas.laine-frigren@tuni.fi

(C) The Author(s) 2022

V. Kivimäki, P. Leese (eds.), Tramma, Experience and Narrative in

Europe after World War II, Palgrave Studies in the History of Experience, https://doi.org/10.1007/978-3-030-84663-3_6
} 
life-changing adventures. ${ }^{1}$ These lost childhoods were not only a painful reminder of the experiences of wartime violence and upheaval, but were also brandished as symbols in discussions about the reconstruction of Europe. To counteract the psychological legacy of wartime violence, children (and their families) came to occupy a privileged position in many postwar societies. After the traumatic experiences of war, the children were seen both as vulnerable and in need of protection, but also as potentially dangerous and in need of control due to the "war inside" that they now suffered from. As a consequence, new psychological theories of healthy and harmonious childhoods and family life occupied the policymakers in postwar welfare states. ${ }^{2}$

This chapter examines how children's wartime suffering was culturally constructed in the particular time-bound context of victimhood and trauma in postwar Hungary. By analyzing a variety of source materials, such as published expert discourse, journalism and ego documents, I explore how children's suffering was interpreted in different contexts. I also examine how the processes of healing were understood, and what kind of social and political meanings were attributed to the children's traumas. My particular focus is the agency of people who did the actual practical work with children, such as psychologists, teachers and civil society activists, but I also refer to political and ideological constructions of childhood. Moreover, I make a tentative distinction between children as victims and children as sufferers in order to suggest (i) that not all war-related suffering found its manifestation in postwar public constructions of victimhood; and (ii) that there was in fact a wide range of war-related experiences among children.

After World War II, Hungary was economically and socially in ruins. The "last ally" of Hitler was now a defeated country, occupied by the Red

${ }^{1}$ Tara Zahra, The Lost Children: Reconstructing Europe's Families after World War II (Cambridge, MA: Harvard University Press, 2011), 90.

${ }^{2}$ Michal Shapira, The War Inside: Psychoanalysis, Total War and the Making of the Democratic Self in Post-war Britain (Cambridge: Cambridge University Press, 2013); Mathew Thomson, Lost Freedom: The Landscape of the Child and the British Post-war Settlement (Oxford: Oxford University Press, 2013); Stefania Bernini, "Mothers and children in post-war Europe: Martyrdom and national reconstruction in Italy and Poland," European Review of History: Revue européenne d'histoire 22:2 (2015), 242-58; Heide Fehrenbach, "War Orphans and Postfascist Families: Kinship and Belonging after 1945," in Histories of the Aftermath: The Legacies of the Second World War in Europe, ed. by Frank Biess and Robert G. Moeller (New York: Berghahn, 2010), 175-95. 
Army and governed by the Soviet-led Allied Control Commission. ${ }^{3}$ Hundreds of thousands of Hungarian Jewish citizens had died in Auschwitz, and the revisionist politics of the interwar period had reached a dead end. ${ }^{4}$ Masses of half-orphaned, orphaned and homeless children were living in general poverty and destitution. ${ }^{5}$ Social welfare institutions were hit hard by the war, and these already chaotic conditions were aggravated by the additional lack of schools, kindergartens and orphanages. ${ }^{6}$ For thousands of children, hiding in shelters, bombing, devastation and death had been among their first experiences of life. In the midst of these generally miserable conditions, however, there was a certain political dynamism and optimism, particularly among left-wing psychologists and intellectuals whose position in the former regime had been insecure (due to antisemitism, for instance), but who now saw the postwar political constellation coalescing before their eyes as something altogether more promising. The psychological profession, for instance, was growing and it adopted a left-wing, progressive and public policy-oriented stance. ${ }^{7}$ From 1945-1947, a national network of child psychology centers began to be set up by the state, ${ }^{8}$ and the "Association of Mental Health Protection"

\footnotetext{
${ }^{3}$ Peter Kenez, Hungary from the Nazis to the Soviets: The Establishment of the Communist Regime in Hungary, 1944-1948 (New York: Cambridge University Press, 2006), 60-80.

${ }^{4}$ Raz Segal, "Beyond Holocaust Studies: Rethinking the Holocaust in Hungary," Journal of Genocide Research 16:1 (2014), 1-23.

${ }^{5}$ There is no exact information on the number of how many orphaned or homeless children lived in Hungary after World War II. Somewhat confusingly, the contemporary postwar estimates vary between hundreds of thousands and tens of thousands. UNESCO (1947) and the American Hungarian Aid Campaign (1945), for example, estimated that there were around 200,000 homeless children in postwar Hungary. In 1948, child psychologist Margit Hrabovszkyné Révész wrote that 20,000-25,000 children were "afflicted by war," but this figure is certainly too low. See Children of Europe (UNESCO, 1947); Margit Hrabovszkyné Révész, "Háborúsujtotta gyermekek," Köznevelés 4:22 (1948), 555.

${ }^{6}$ The postwar situation for children's health was also very bleak. In 1946, for example, over 40 percent of school-aged children were diagnosed with severe anemia, while diseases such as typhoid and tuberculosis were also very common. See Szabolc Varga, "A gyermekvédelem Magyarországon, különös tekintettel Sopron vármegyére (1945-1950)," Universitatis Szegediensis: publicationes doctorandorum juridicorum 6:1-8 (2004), 199.

${ }^{7}$ Melinda Kovai, Lélektan és politika: Pszichotudományok a magyarországi államszocializmusban 1945-1970 (Budapest: L'Harmattan Kiadó, 2016), 143; Tuomas Laine-Frigren, Searching for the Human Factor: Psychology, Power and Ideology in Hungary during the Early Kádár Period (Jyväskylä: University of Jyväskylä Press, 2016), 206, http://urn.fi/ URN:ISBN:978-951-39-6536-5

${ }^{8}$ Kovai (2016), 151-2.
} 
was formed, grouping together progressive professionals from a number of fields and having the support of the Communist establishment and those in charge of science policy. ${ }^{9}$ Following trends elsewhere in the world, and supported by the concrete aims of the country's top politicians, psychology professionals and educators in Hungary now began to plan new socialist policies for child welfare and education. ${ }^{10}$

Childhood during World War II has already been the subject of many important studies, ${ }^{11}$ and there are also an increasing number that focus on postwar childhoods. ${ }^{12}$ Many of the latter have focused on both the practical and theoretical work of civil activists, psychiatrists, teachers and social workers who dealt with these war children. Machteld Venken and Maren Röger, for instance, write about a Polish primary-school teacher in the provincial town of Submierzyce who in 1946 encouraged pupils to make drawings of what they had experienced in the war, drawing particular attention to the work of one boy who had experienced being a child forced laborer. ${ }^{13}$ Meanwhile, the historian Ellen Schrumpf analyzes the essays of Norwegian schoolchildren asked to write stories about their life under the German occupation (1940-1945). ${ }^{14}$ Ulrike Präger, in turn, investigates

9 “Egy meg nem jelent folyóirat-a Jövő Embere," Thalassa 6 (1995), 1-2, 233-4, 248.

${ }^{10}$ Géza Sáska, "Alkalmazott lélektan és reformpedagógia 1945 után: Értelmezési kísérlet II rész," Beszélo" 13:2 (2008), 6. Jewish left-wing psychologists and psychoanalysts in particular saw the general political conditions as promising; Kovai (2016), 137-52.

${ }^{11}$ See, for example Gabriel Moshenska, Material Cultures of Childhood in Second World War Britain (London: Routledge, 2019); Martin Parsons. War Child: Children Caught in Conflict (Cheltenham: The History Press, 2008).

${ }^{12}$ Machteld Venken and Maren Röger, "Growing up in the shadow of the Second World War: European perspectives," European Review of History: Revue européenne d'histoire 22:2 (2015), 199-220; Juliane Brauer, "Disciplining Young People's Emotions in the Soviet Occupation Zone and the Early German Democratic Republic," in Childhood, Youth and Emotions in Modern History: National, Colonial and Global Perspectives, ed. by Stephanie Olsen (Basingstoke: Palgrave Macmillan, 2015); Tuomas Laine-Frigren, "Children on the Move: Psychiatric Encounters with Child Evacuees Returning to Post-war Finland," in Social Class and Mental Illness in Northern Europe, ed. by Petteri Pietikäinen and Jesper Vaczy Kragh (London: Routledge, 2019); Nick Baron, ed., Displaced Children in Russia and Eastern Europe, 1915-1953: Ideologies, Identities, Experiences (Leiden: Brill 2016).

${ }^{13}$ Venken and Röger (2015), 199.

${ }^{14}$ Ellen Schrumpf, "Children and Their Stories of World War II: A Study of Essays by Norwegian School Children from 1945," in Nordic Childhoods 1700-1960: From Folk Beliefs to Pippi Longstocking, ed. by Reidar Aasgaard, Marcia Bunge and Merethe Roos (New York: Routledge, 2018), 205-19. Keeping in mind the multi-layered character of these narratives, Shrumpf detected many kinds of story types, from heroic adventures to tragic encounters 
the "musical recollections" of German children expelled from the Sudetenland (as well as those who stayed there)-discussing the role of music in mitigating the traumas of war and loss of homelands; ${ }^{15}$ while Viktória Bányai and Eszter Gombocz have noted that a similar therapeutic use of art was practiced in postwar Budapest, too. ${ }^{16}$ In the Hungarian context, the outstanding work done by the social historian, Gergely Kunt, on wartime and postwar teenage diaries has been particularly valuable. ${ }^{17}$

The present study contributes to these wider historiographical trends by approaching the history of traumatized children in postwar Hungary from the two perspectives of discourse and encounter. In the first part of this chapter, I make use of Jeffrey C. Alexander's theories on trauma to examine how the discourse surrounding children's victimhood ensured that their suffering was interpreted as a painful "social wound," and consequently used to serve particular social and political ends. ${ }^{18}$ In the second part of this chapter, I focus on the actual encounters between traumatized children and the adults who tried to help them. First, I look at one particularly interesting experiment in poem therapy that was carried out by a literature teacher in 1946 together with homeless children. After that, I look beyond the public "trauma drama" of children into a more personal account by examining the extraordinary wartime memoir and diary written by a volunteer nurse and Jewish survivor, Margit Tolnainé Kassai (1909-2000).

with death and loss, thus studying exactly how these stories stemmed from children's lived experience.

${ }^{15}$ Ulrike Präger, “'Musicking' Children From the Bohemian Lands: Nurtured and Hidden Musical Practices on Both Sides of the Iron Curtain," European Review of History: Revue européenne d'histoire 22:2 (2015), 310-30. See also Beata Halicka, "The Everyday Life of Children in Polish-German Borderlands During the Early Postwar Period," in Borderland Studies Meets Child Studies: A European Encounter, ed. by Machteld Venken (Frankfurt am Main: Peter Lang, 2017), 115-37.

${ }^{16}$ Viktória Bányai and Eszter Gombocz, "A traumafeldolgozás útjain: Holokauszt-túlélo” gyerekek Magyarországon, 1945-49,” Regio 24:2 (2016), 44.

${ }^{17}$ Gergely Kunt, Kamasztükrök: A hosszú negyvenes évek társadalmi képzetei fiatalok naplóiban (Budapest: Korall, 2017); Gergely Kunt, "The Psychological Coping Mechanisms of a Jewish Hungarian Teenager, Lilla Ecséry, as Reflected in Her Diary Written during the Holocaust," Judaica et Holocaustica 7 (2016), theme issue Women and World War II, 69-89.

${ }^{18}$ Jeffrey C. Alexander, Trauma: A Social Theory (Cambridge: Polity Press, 2012), Introduction, 101, 146. 


\section{Children as Victims}

The end of the war in Europe saw many children whose mental well-being had been greatly affected by the violence they had experienced; and for whom there was now an increasing interest in their plight. Psychology experts and social workers, as well as state officials all around Europe, were very concerned that these children and adolescents might perhaps be too damaged to become active democratic citizens within postwar society. As Tara Zahra has shown, the sorry physical and mental state of the children caused many people at the time to fear for the future. Many worried, for example, that numerous children had been infected by the "foul education" provided by the fascists, while others were simply alarmed by the all-too-accurately dubbed "wolf children."19 In Hungary, Gábor Sztehlo (1909-1974), Lutheran pastor and founder of the children's home Pax, ${ }^{20}$ described how, in 1948, one of his children had spent one and a half years traveling across four countries fruitlessly looking for his father-all before the age of 12. The child eventually made it to the Austrian border where he fell into the hands of American soldiers, but only after having first wandered through Czechoslovakia and Romania. Sztehlo also described the feral appearance of another (13-year-old) boy who, upon arrival, was "almost naked and full of wounds," and "only carrying a flute [... $]. " 21$ Meanwhile, in an account of what it was like working immediately after the war, a teacher from the village school of Uciechów in Lower Silesia, Poland, recalled the fate of those children who had arrived in the village after being transported all the way from the Ukraine. "These were big and small savages, almost all of whom had some psychological trauma, which was no wonder. After all, some of them had survived only by chance, hidden in some corner of the house in which some "hajdamaks'22 had slaughtered their closest relatives [...]." 23 Indeed, it would seem that a huge number of children in East-Central Europe had suffered traumas during

${ }^{19}$ Tara Zahra, "Lost Children: Displaced Children Between Nationalism and Internationalism after the Second World War," in Baron, ed. (2017), 198.

${ }^{20}$ This was a children's home and social facility for war orphans and other endangered children in Budapest.

${ }^{21}$ Andor Zsoldos, “Csoda a Budai Hegyek között,” Haladás 3:27 (1947), 9.

${ }^{22}$ The word "Hajdamak" historically refers to a Ukrainian Cossack paramilitary fighter. In Poland, the term Hajdamactwo has very negative connotations, sometimes referring to Ukrainians as a whole.

${ }^{23}$ Halicka (2017), 131-2. 
the 1940s caused by dislocation, hunger, violence and the loss of loved ones.

As also pointed out in Anna Wylegała's chapter in this book, the war experiences of these children were many and varied. In 1948, Hungarian journalist, Margit Izsáky (1899-1977), interviewed a number of underage conscripts who had been forcefully drafted during the last months and even weeks of war to fight an increasingly desperate struggle against the advancing Soviet Army. Izsáky was preparing a book about peoples' everyday lives during and after the Budapest siege. She was an experienced reporter and a specialist at investigating issues such as poverty and juvenile delinquency. In her book, which was soon to be published under the title, Ország a Keresztfán ("A Country on the Cross"), she reported on the day-to-day hunger and hardships of life in the bomb shelters during the last months of war, but her fundamental message was related to major issues of social and moral responsibility-and she started with the fate of children such as the ones mentioned below. ${ }^{24}$

The 15-16-year-old boys that Izsáky met all belonged, like most of their peers, to the nationalist paramilitary organization known as Levente - a nationwide youth organization (est. 1921) that provided military training for all Hungarian boys between the ages of 12 and 21 . Throughout the war, Levente members had been actively involved in many kinds of military duties (e.g., as air-raid and fire wardens), but after the Arrow Cross coup in October 1944, they were increasingly used in combat situations. ${ }^{25}$ Izsáky started her book with a description of these boys as having the appearance of "bitter old men," after the physical and mental stress they had clearly suffered at the hands of superior officers who had treated them very harshly. ${ }^{26}$ This topic was also being discussed in the

\footnotetext{
${ }^{24}$ Margit Izsáky, Ország a keresztfán (Budapest: Müller Károly Könyvkiadó Vállalat, 1945). Izsáky's book was one of eight volumes in the Hungarian "Golgota" series (published in 1945). The openly expressed aim of Magyar Golgota was to stimulate discussion about the disaster of the recent past. See also Máté Zombory, "Magyar golgota: Politikai közösség és múltreprezentáció 1945 után," Szociológiai Szemle 25:1 (2015), 66-88.

${ }^{25}$ Attila Horvath, "War and Peace: The Effects of World War II on Hungarian Education," in Education and the Second World War: Studies in Schooling and Social Change, ed. by Roy Lowe (London: Routledge, 1992), 147-8; Caroline Mezger, Forging Germans: Youth, Nation, and the National Socialist Mobilization of Ethnic Germans in Yugoslavia, 1918-1944 (Oxford: Oxford University Press, 2020), 188-9. Levente initially recruited only boys, but from 1942 onwards girls were also encouraged to join. This was voluntary at first but became obligatory after the takeover by Arrow Cross.

${ }^{26}$ Izsáky (1945), 13.
} 
Hungarian Parliament at the time; as one MP pointed out in November 1945, many of these young Levente teenagers were now suffering in "unbearable circumstances" as prisoners in Allied-occupied Austria and Germany-it was high time to bring them back. ${ }^{27}$ For Izsáky, these traumatized boys were not only victims of Arrow Cross and SS brutality, but also of a more generalized lack of moral responsibility and lack of courage on the part of adults to defend the children. ${ }^{28}$

Izsáky also met two teenage boys who had been given long prison sentences by the postwar Peoples' Court ${ }^{29}$ for having taken part in the Arrow Cross's reign of terror-in particular, the infamous death march out of Budapest in which many Jews had been beaten to death. In one thoughtprovoking scene, the focus was thus turned towards the emotionally charged issue of children as potential perpetrators. Izsáky tried to describe how she felt in "the prison corridor" on her way to meet one of these boys. In spite of the fact that she had "already got used to the idea that the whole world was clearly one big mental asylum, full of evil imbeciles," she had to admit that it "was really scary" to think she was now going to meet convicted murderers who were barely teenagers. ${ }^{30}$ But these were not psychopaths, she found, just kids from extremely poor backgrounds with little education- "typical Arrow Cross types," as she put it-who probably thought that messing around with submachine guns was a kind of game or "adventure." As twisted as these kids most certainly were, they were also clearly the victims of "poisonous, racist, and fascist propaganda" and the "worst kind of pulp fiction." Indeed, together with the misery they had "inherited," all these factors had combined to unleash their "murderous instincts." However, she was careful to play down the distinction between victim and perpetrator by also acknowledging that she, too, felt a certain responsibility (as indeed the whole country should have) for what had

${ }^{27}$ A nemzetgyülés 2. ülése 1945. november hó 30-án, pénteken. The MP also referred to Hungarian Jewish children (although he did not explicitly call them Jews), who had somehow managed to survive being deported, but who were still in Austria and Germany. https:// library.hungaricana.hu/hu/collection/ogykdok_1945_1947/ (last accessed 23 January 2021).

${ }^{28}$ Izsáky (1945), 7-13.

${ }^{29}$ Between 1945 and 1950, more than 40,000 cases were heard in the Communist-led People's Tribunals, and over 22,000 defendants were found guilty. Tamás Bezsenyi and András Lénárt, "The Legacy of World War II and Belated Justice in the Hungarian Films of the Early Kádár Era," Hungarian Historical Review 6:2 (2017), 302.

${ }^{30}$ Izsáky (1945), 14-5. 
happened: "I cannot feel pity - I only feel ashamed of myself. What kind of people did this to them? We are all guilty!" ${ }^{31}$ In this way she not only claimed that adults should take real responsibility, but also raised the otherwise unspoken issue of collective guilt and perpetratorhood. The issue of children as potential perpetrators was thus used to illustrate broader cultural traumas in a country that had fought side-by-side with the Nazis.

In the immediate postwar years before the Communist takeover in 1948-1949, a large number of books and pamphlets were published, dealing with experiences of the recent past and the lessons that might be learned from them. ${ }^{32}$ Among these were autobiographical narratives describing the Hungarian and Nazi German persecution of Jews, written by both Jewish and non-Jewish Hungarians. ${ }^{33}$ Intellectuals raised questions about moral responsibility and soul-searching, while leftists especially blamed the "counter-revolutionary" regime of Miklós Horthy-at least in its last days, when the Arrow Cross members were given free reign-for having destroyed people's sense of morality. As the avant-garde writer, Lajos Kassák, put it-repairing these "poisoned minds" would not be something that could be done simply overnight. ${ }^{34}$ Indeed, the problem was thought to be widespread; in 1945, the poet and politician, Dezső Keresztury, argued that the nation had been thrown into such a state of moral darkness by the terrible events of the recent past that "not even a lantern would help pick out a single person free of blame for what had happened in one way or another." 35 This was precisely the kind of discourse which used the symbol of the child as victim (and perpetrator) to highlight both a political community in crisis and the need for reconstruction and reform.

One rather typical way to articulate children's victimhood was to blame the "fascist" education they had been subjected to, and its dire consequences. This was a crucial subtext in Alice Hermann's arguments about the negative consequences of an authoritarian upbringing. Hermann (1895-1975) was one of the many left-leaning psychologists and child experts in postwar Hungary. An activist in the Social Democratic Women's movement, and a trained psychoanalyst, she represented the pre-war

${ }^{31}$ Izsáky (1945), 14-5.

${ }^{32}$ Zombory (2015).

${ }^{33}$ Ferenc Laczó, Hungarian Jews in the age of Genocide: An Intellectual History, 1929-1948 (Leiden: Brill, 2015), 134.

${ }^{34}$ Lajos Kassák, "Vissza az életbe," Világ, 18 May 1948.

${ }^{35}$ See Dezső Keresztury, “Ember, ember, ember kívántatik,” Szabad Szó, 15 June 1945. 
heritage of the Budapest School of Psychoanalysis founded by Sándor Ferenczi (1873-1933). In 1946, Hermann published a popular guidebook entitled Emberré Nevelés ("Educating Humans"). Written against the backdrop of extreme violence in 1944-1945, the book at once advocated a liberal and humanist approach to education as the best means to avoid the dark past repeating itself and followed in the Hungarian psychoanalytic tradition. Indeed, the critique of conservative education-its hypocritical endeavor "to save the child's soul by severity" - had been at the core of Sándor Ferenczi's psychoanalytic work. ${ }^{36}$ Most importantly, Ferenczi's conception of trauma being a consequence of broken social bonds was fundamentally based on his realist understanding of children's experience of parental violence and abuse. ${ }^{37}$

It was only logical that one of the major topics in Hermann's book would be authoritarian upbringing. She illustrated her ideas with a scene she had once witnessed in a Budapest marketplace when a mother hit her seven- or eight-year-old boy for running out after her as she left the house because he did not want to be left home alone. For Hermann, it was a clear illustration of how punishing children arbitrarily would breed submissive, fearful and timid human beings: well-behaved for sure, but ones whose "greatest satisfaction [would be] to follow the rules." Children so raised would never develop the capacity for making proactive and autonomous decisions. Instead, their sense of responsibility would extend "only to the point at which $[\ldots]$ the mission was completed and the command fulfilled." 38 What Fascism had revealed, Hermann argued, was not that the (German) people were themselves inherently cruel, but that since childhood they had been deeply ingrained with a "cult of obedience" which would explain why one day they might be organizing "Kraft durch Freude activities" 39 and on another "organizing pogroms." 40

\footnotetext{
${ }^{36}$ Ferenc Erös, "Violence, Trauma and Hypocrisy," in Psychology and Politics: Intersections of Science and Ideology in the History of Psy-Sciences, ed. by Anna Borgos, Ferenc Erös and Anna Gyimesi (Budapest: CEU Press, 2019), 82-3, passim.

${ }^{37}$ Sándor Ferenczi, "Confusion of the Tongues Between the Adults and the Child (The Language of Tenderness and of Passion)," International Journal of Psycho-Analysis 30 (1945/1932), 225-230, translated by Michael Balint, https://icpla.edu/wp-content/ uploads/2012/11/Ferenczi-S-Confusion-of-Tongues-Intl-J-Psychoa.-vol.30-p.225-1949. pdf (last accessed 23 January 2021).

${ }^{38}$ Hermann (1946), 34-5.

${ }^{39}$ Kraft durch Freude (Strength through Joy), or $K d F$, was a leisure organization for workers and their families in Nationalist Socialist Germany.

${ }^{40}$ Hermann (1946), 34-5.
} 
On 12 November 1947, the topic of victimized children clearly became a vehicle for promoting a range of political agendas, when a parliamentary session $^{41}$ was called to debate a bill for establishing a new Juvenile Court in Budapest. Many of the speakers supported the rational and humanist idea that the Juvenile Court should use psychological expertise to help young delinquents readjust to society, ${ }^{42}$ but many also used very pointed rhetoric to condemn the pre-war regime for what it had done to children.

Dénes Huszti, for instance, from the Smallholder's Party, talked about the "false patriotism" that had been peddled; he pointed out that children were universally very responsive to "all that was beautiful and noble," but since the old regime had failed to give them a proper humanist education, they had been easily marshaled in the wrong direction. The horrible events of the Jewish death march in 1944 were a testament to this. "Those of you who witnessed it," he argued, "will never forget the image of innocent people marching towards defamation and death," accompanied by 14-15-year-old bullies, who were beating and shooting dead anybody who faltered or tried to escape. ${ }^{43}$ The Social Democrat MP, György Faragó, also referred to these "killing sprees" 44 in an attempt to make the listeners more responsive to child-related institutional reforms. Indeed, both Huszti and Faragó were keen to support the new proposals that psychology professionals work beside the judge in Juvenile Court to make sure that justice would be based on prevention, emphatic understanding and rational guidance-instead of punishment and nothing else. ${ }^{45}$

The Social Democrat, Fanny Auer (Ernőné Hajdú), gave one of the most powerful speeches of the day. She attacked an inherently conservative legislation which, because it had been "written by men," she argued, was blind to the occurrence of young girls being sexually abused (which was in turn a major cause of prostitution). ${ }^{46}$ Auer also made positive remarks about new experiments in collective education and orphan care (e.g., Pax in Budapest), and demanded more psychology-based policies

${ }^{41} \mathrm{Az}$ országgyűlés 18. ülése 1947. évi november hó 12-én, szerdán, https://library.hungaricana.hu/hu/collection/ogykdok_1945_1947/(last accessed 23 January 2021).

${ }^{42} \mathrm{Az}$ országgyűlés 18. ülése 1947. évi november hó 12-én, szerdán, 905-6, https:// library.hungaricana.hu/hu/collection/ogykdok_1945_1947/ (last accessed 23 January 2021).

${ }^{43}$ Ibid., 904.

${ }^{44}$ Ibid., 888.

${ }^{45}$ Ibid., 888-9, 905-6.

${ }^{46}$ Ibid., 912. 
for dealing with the menacing prospect of childhood crime in postwar Hungary. She believed the children would not easily forget the violence they had experienced, having internalized dangerous behavioral patterns during the war and the difficult times that followed it. "What should we expect," she asked, "from teenagers who saw and took part in so much killing themselves, who took part in looting homes and shops, and when the smartest kid in the family was the one who brought home as much of that loot as possible?"

\section{The Psychology of Childhood Trauma}

After the violent upheavals of World War II, social planners around Europe became more receptive to child psychiatry and psychology. As Michal Shapira and others have shown, the fate of children during the war and its aftermath provided a testing ground for psychological theories related to child development. ${ }^{47}$ In Great Britain, Anna Freud and Dorothy Burlington famously voiced their concern over the evacuation of children from metropolitan areas to the British countryside. States and professionals were relying on findings made in the pre-war period, which had already seen a wide range of interventions in childhood issues, ${ }^{48}$ and the emergence of the "child" as a key factor (and potential threat) for the future health and versatility of the nation. ${ }^{49}$

Hungary had an internationally significant tradition of child psychology, psychoanalysis and education, which now found fertile ground in the leftist (but still relatively pluralist) political context of the immediate postwar years before the Communist takeover. In light of the source material, however, the psychological consequences of war and genocide for children were rarely the main focus of expert discourses in postwar Hungary, ${ }^{50}$ and

\footnotetext{
${ }^{47}$ Shapira (2013).

${ }^{48}$ See, for example, Dirk Schumann, ed., Raising Citizens in the "Century of the Child": The United States and German Central Europe in Comparative Perspective (New York: Berghahn, 2011); Nikolas Rose, Governing the Soul: The Shaping of the Private Self (New York: Cambridge University Press, 1999) 123-213.

${ }^{49}$ See, for example, Bengt Sandin, "Children and the Swedish Welfare State: From Different to Similar," in Reinventing Childhood after World War II, ed. by Paula S. Fass and Michael Grossberg (Philadelphia: University of Pennsylvania Press, 2011). Jutta Ahlbeck, "The Nervous Child and the Disease of Modernity," in Childhood, Literature and Science, ed. by Jutta Ahlbeck et al. (London: Routledge, 2018).

${ }^{50}$ The lack of explicit public attention of social and individual tragedies caused by war most clearly concerned the adult traumas. As observed by Melinda Kovai, this was particularly
} 
when these matters were discussed by psychologists, that tended to happen in the future-oriented context of preventive strategies for mental health and democratic education. However, the professional opinions of psychologists were becoming increasingly visible and were often cited in the press. In October 1947, for example, a psychologist from the Budapest Institute for Child Psychology advised families not to send their small children to the countryside in winter. Referring to British wartime experiences, the psychologist argued that being separated from the mother was even more dangerous for a child than any poverty and deprivation they might experience at home. ${ }^{51}$

The wartime traumas of children were a direct cause of concern for Dr. Margit Hrabovszkyné Révész (1885-1956), who published an extensive study on "war-afflicted" children in 1948. ${ }^{52}$ Between 1 May 1945 and 30 June 1948, Dr. Révész examined 226 children at the aforementioned Pax children's home (founded by Gábor Sztehlo), also known as Gaudiopolis ("the City of Joy") at the time..$^{53}$ Gaudiopolis was not only a child-welfare institution but also a large-scale collective experiment in civic education, a kind of city-state for children (that was also run by them).${ }^{54}$ Its roots were in the wartime rescue operations that Sztehlo had led, supported by the International Red Cross, using his Lutheran "Good Shepherd" orphanages to shelter around 1600 Jewish children and 400 adults during the Arrow Cross reign of terror and siege of Budapest in $1944-1945 .{ }^{55}$ During its five years of existence (1945-1950), Gaudiopolis housed several

manifest during the first large psychiatric conference after the war in Hungary: only one of the speakers referred to mental problems caused by war. See Kovai (2016), 131. See also Ran Zwigenberg, "'Wounds of the Heart:' Psychiatric Trauma and Denial in Hiroshima," History Workshop Journal 84 (2017), 67-88. By now, many studies have argued that in many countries, war-related adult traumas (e.g., in soldiers) were not really understood or accepted by the mental health establishment after World War II.

${ }^{51}$ József Péter, “Gyermek-teleltetés," Magyar Nemzet, 19 October 1947, 4.

${ }^{52}$ Hrabovszkyné Révész (1948), 555-62.

${ }^{53}$ Zsoldos (1947).

${ }^{54}$ Stehlo's Gaudiopolis was a direct inspiration for Géza Radványi’s classic film Somewhere in Europe (Valahol Európában, 1948), which depicts a gang of orphaned children building a new civilization out of the ruins of war. See Constantin Parvulescu, Orphans of the East: Postwar Eastern European Cinema and the Revolutionary Subject (Bloomington: Indiana University Press, 2015), 17-43.

${ }^{55}$ Éva Makai, "Háborús évek gyermekvédelmi közösségek utópiai," Iskolakultúra 6:2 (1996), 94-7. 
hundred endangered children with different social backgroundsalthough most had been either orphaned or half-orphaned by the war.

In her article, Révész presented a number of case studies, with her main intention being to show that children with different life histories, social backgrounds and ways of reacting to traumatizing events should be treated in different ways from each other. During the many moments she had spent with them over the years, she had noticed that many suffered from difficult inner conflicts, "persistent anxieties" and "fear of death." She believed the most important way to help these "mentally wounded" (lelkileg sérült) and "fearful" children was to give them moments of joy, beginning with a good regular diet and plenty of room to play and move around. Children's "natural curiosity," so often suppressed by the traumas they had suffered, should be revived by taking them on nature trips, giving them books or by taking them to see a film. Only after their basic emotional and "instinctive" needs were first met, could school assignments and other work tasks be set. In this way, it was hoped they could gradually shake off the debilitating sadness caused by the chronic lack of love and support they had suffered. ${ }^{56}$ But as some of the children reacted aggressively and antisocially_needing to feel more active in actually controlling their environment - it was decided they should be given meaningful social roles in the community. In this way, Révész reasoned, their activity could be channeled to a "higher cultural level"-in which they could genuinely feel they were contributing to the children's community. Clearly, the civic and democratic upbringing offered by Gaudiopolis was one way to do this.

As noted by Constantin Parvulescu, orphans soon came to symbolize the allegedly superior social bonds represented by the socialist state in postwar Central and Eastern Europe. Révész, too, promoted the ideal of a benevolent institution, which, via individual teachers and other workers, would offer the kinds of psychological support that had previously only been entrusted to families (especially mothers). In her estimation, the orphans really longed for concrete support and help, and so when they got this, they tended to become the "very grateful" pedagogical subjects of those who truly took care of them, keen to identify the supportive

\footnotetext{
${ }^{56}$ Révész (1948), 561. Interestingly, Révész also related to physical symptoms. As she wrote, during the first months after the Budapest siege, the symptoms of mental trauma were primarily to be seen in "drastically reduced physical resistance," for example, prolonged gastrointestinal inflammation and various kinds of skin problems. In addition to them, very persistent "fear states" were the most striking phenomena during the first postwar months.
} 
educator with the "missing parent" and the institution with a lost home. Révész recommended this humanistic institutional path particularly in those cases where the child's mother had died, as the mental wounds of these children often went unnoticed in family-care situations; especially when those families had themselves often been "mutilated" in so many ways.

The postwar momentum for psychology-based reforms was not solely driven by those in power and professionals in Budapest. There were also many teachers outside the capital with an interest in applied child psychology. ${ }^{57}$ One of these teachers was Livia Koralek, who had carried out psychological association tests with 55 orphaned Jewish children and detailed them in a report about her experiences in $1946 .{ }^{58}$ The terms she used in the tests were "war," "home" and "mother," and the result she came away with was that all three were linked to "death and destruction" for these children. However, she argued that if teachers could develop ways of really listening to children's feelings, they could devise ways of alleviating their suffering and "make them smile again." In her opinion, it was the teacher's task to make the children realize that "nobody could ever again treat them in the way they had been treated a year ago." Only then could they, at some point, eventually realize there was in fact "a country waiting for them, and a country [Hungary] worth fighting for." Perhaps the children might gradually even forget their suffering. There was actually some reason for optimism, because several of her children "already knew how to laugh." 59

One way of helping the children, Koralek suggested, would be for them to cultivate their own communities. Maybe the terrible things they had experienced in wartime could be something that provided the necessary impetus for building a "better future" together, insofar as they were events that they would absolutely want to avoid. She even went so far as to claim that their bad experiences had given them a certain "social awareness" 60 that their "Jewish brothers" had received more than their share of

${ }^{57}$ Kovai (2016), 150.

${ }^{58}$ Lívia Koralek, “A második világháború hatása a zsidó gyermek lelkivilágára,” in Tarbut Héber Kultúregyesïlet iskoláinak Évkönyve az 1945-46-os tanévröl, ed. by Aladár Spiegel (Budapest, 1946).

${ }^{59}$ Koralek (1946), 17.

${ }^{60}$ Koralek was clearly influenced here by the Hungarian pioneer of child studies, László Nagy (1857-1931), who had also detected war-induced "social sentiments" in his study of children's perceptions of war during World War I. See László Nagy, A báború és a gyermek 
suffering, ${ }^{61}$ thus also suggesting that the adults might also learn something from these children. The historian Gabriel Finder has also discovered somewhat similar images of children in his studies on Jewish child survivors in the Polish postwar collective memory. In a recent article, he focuses on how children were represented in the famous Yiddish film "Our Children" (Undzere Kinder, 1948). ${ }^{62}$ The film dramatizes the encounter between two comedian actors and the residents of a Jewish children's home. The experience gives the children the chance to reflect on their wartime experiences and to criticize the artists' representations. ${ }^{63}$ According to Finder, the children in the home (where most of the film's scenes are located) are portrayed as being terribly scarred by their experiences of the Holocaust, yet they are still able to build some kind of memory community for sharing these experiences together-especially when encouraged through artistic intervention. In this way, survivors of the Holocaust are for the most part depicted in the film as brave and futureoriented agents, rather than as passive victims. The film also suggests that adults can learn directly from children about the mental pain caused by war; about storytelling and music as potential ways of healing; and about how the future should be built. ${ }^{64}$

\section{Children as SufFerers}

Where are you, mummy?

Here I am, my sweet son.

Although I won't see you long.

Come closer, my son.

And if I die.

Who's gonna look after you, my son?

I live on the pavement.

Someone will take me in.

Ernő Szecső ${ }^{65}$ (1947)

lelke: Adatok a gyermek értelmi, érzelmi és erkölcsi fejlodéséhez (Budapest: A Magyar Gyermektanulmányi Tár, 1915), 141.

${ }^{61}$ Koralek (1946), 17.

${ }^{62}$ Gabriel N. Finder, "Child Survivors in Polish Jewish Collective Memory after the Holocaust: The Case of Undzere Kinder," in Baron, ed. (2017), 218-47.

${ }^{63}$ Finder (2017), 229-32. Undzere Kinder is also considered as one of the earliest critical filmic interventions to the problem of Holocaust representation.

${ }^{64}$ Finder (2017).

${ }^{65}$ The original Hungarian poem (translated by the author), written by the young orphan Ernő Szecső, goes as follows: "Hol vagy édesanyám? Itt vagyok édes fiam. Bár nem látlak 
Orphaned children could be seen everywhere in the cities of Central and Eastern Europe by the end of 1945. As Constantin Parvulescu has suggested, their growing presence became a powerful reminder not only of the traumatic experience of war itself, but also the "grim deeds" of their parents' generation; symbolizing both the guilt of perpetratorhood and visions of a new civilization. ${ }^{66} \mathrm{I}$, too, have argued in the first part of this chapter that children's victimhood was brandished ubiquitously in both professional and political discourses that envisioned a better society for postwar Hungary. The poem cited at the start of this section, however, was written as part of a "therapeutic" poetry experiment in a children's home by a teenager called Ernő Szecső whose mother had died. I will look specifically at this experiment next, as an example of a unique way of dealing with children's wartime traumas.

In 1947, teacher Zoltán Rákosi, renowned for his liberal educational ideas and great personality, ${ }^{67}$ published an essay on teaching children about poetry. ${ }^{68}$ Rákosi began by saying how in October 1946, "the learning went just fine," but that he sensed that there was a heavy feeling of resignation in the air that would just not go away. But in July of the following year, the famous poet Sándor Weöres (1913-1989) published a new collection of his poetry, Elysium, which included a children's poem called the "Dancing Song" (Táncdal), that played with nonsensical words, and Rákosi noticed how children would sometimes use a line from this poem they had heard (like "panyigai, panyigai, panyigai $[\ldots]$ "), ${ }^{69}$ and use it for various purposes - as a joke, or expression of pity, for example. Inspired by this, he decided to "stir things up" a bit and challenged his class (mostly boys) by reading a poem he was "sure they wouldn't understand."

Rákosi's essay is a fascinating narrative of pedagogic discovery in the world of poetry; about how he and the kids started playing with rhymes, rhythms and sounds- "chewing" words and studying their emotional

sokáig. Gyere közelebb fiam. S ha meghalok. Ki fog gondozni, fiam? Az utca szélén lakom. Valaki csak befogad."

${ }^{66}$ Parvulescu (2015), 3.

67 “'Erről a családról, amelynek oly sok nevezetes tagja volt’ - Sárközi Mátyással beszélget Hegedu”s B. András,” Beszél”, 22 December 1994 (Karácsonyi melleklét), 14-5.

${ }^{68}$ Zoltán Rákosi, “Gyermekköltészet vagy a 'közönség’ útja a művészethez: Részlet egy általános iskolai magyar tanár naplójából,” Válasz 7:11 (1947), 414-26.

${ }^{69}$ Weöres' poem in English, see https://www.babelmatrix.org/works/hu/ We\%C3\%B6res_S\%C3\%Alndor-1913/T\%C3\%Alncdal (last accessed 23 January 2021). 
effects. Eventually, after several months of practice, the children were writing their own poems-and even got to meet the poet Weöres when he paid a visit to their class in person. In his essay, Rákosi clearly wants to convey the importance of a dialogic way of teaching; he was quite cleverly using children's existing ideas of poetry, but at the same time encouraging them to express even their strangest opinions and feelings. This method seems to have been successful: as one of the boys had revealed to Rákosi, "a peculiar feeling, difficult to grasp, grew inside me; it was mixed with pain $[\ldots]$ then I felt like I had grown wings and was now flying faster than the wind into the big world out there." 70

Rákosi wrote in a self-reflective and gently ironic style, constantly weighing in on his role as a teacher, at the same time giving the impression that he, too, was participating in poetic discovery through playing. In 1994, one of his former students captured this playful aspect of his former teacher when remembering how they had gone on "strike against Mr. Rákosi's beard," refusing to participate in lessons again until the teacher shaved off his beard. This demonstration of the "will of the people" conveys something of the ideological sensibilities in postwar Hungary. ${ }^{71}$ Not that Rákosi was a dogmatic ideologue; he wanted rather to inculcate a self-conscious and independent style of thinking among his pupils, as well as a love for the "music of poetry." This was not for any sublime nationalistic or collectivistic reason, but for the sake of art and life itself, even if it meant that the "statue of the Great Poet" would have to be toppled. ${ }^{72}$

Many of Rákosi's fifth grade elementary school students were badly traumatized Jewish children; and interestingly, the experiment itself took place in Sztehlo's aforementioned Gaudiopolis. As an educational institution, it combined early twentieth-century reform pedagogy, postwar socialist-democratic collectivism and Sztehlo's own experiences of the practice-oriented educational methods of the Finnish Folk High School movement, covering activities such as handicrafts, music, sports and hiking (Sztehlo had acquired a two-year fellowship to study theology and pastoral work in Finland at the turn of the 1930s). ${ }^{73}$ For some reason, Rákosi did not mention in his essay that his students were from Gaudiopolis

${ }^{70}$ Rákosi (1947), 416.

71 "Erről a családról” (1994), 14.

${ }^{72}$ Rákosi (1947), 420.

${ }^{73}$ Charles Fenyvesi, When Angels Fooled the World: Rescuers of Jews in Wartime Hungary (London: University of Wisconsin Press, 2003), 169; Makai (1996), 94-7. Based on his Finnish experiences, Sztehlo established a folk high school in Nagytarca (east from Budapest) 
(maybe he wanted people to see his pedagogy as having more universal value). His primary aim was also not so much to disseminate a model of "art therapy" for traumatized children, but to recount the educational discoveries he had experienced together with his pupils.

Rákosi's article did, however, include both implicit and explicit references to the children's suffering. For example, in response to negative and sometimes rude feedback from children's relatives; claims from teachers and educational authorities that Rákosi's liberal methods were ruining the school's "prestige"; and letters accusing him of being "antisocial" and "inciting" hatred against the working class, ${ }^{74}$ Rákosi made it very clear just how much his pupils had suffered during the war. He also pointed out how his critics had not noticed the importance of the poetry experience for the children-how it had truly affected their mental lives by, for instance, increasing their sense of belonging and inner purpose. In comparison, he noted that, after having been away for a couple of weeks over Christmas, the boys had become "orphans once more; pale and lifeless, they lingered around without a sense of purpose in their lives. It took several weeks of conscious caring to give them back peace of mind and the joy of poetic creation." 75

Significantly, Rákosi was using poems that he must have known would have an emotional effect on homeless children: when the class studied a poem by János Arany (1817-1882), called Family Circle ("Családi kör"), he quickly recognized the emotions thrown into stark relief by the "light of the fireplace," which was "shining so invitingly" for these homeless children. At this point, he instantly began to suspect that the poem might easily lose its appeal if they tried to analyze it too closely. In any case, the poem certainly seemed to affect the children - they even used it to dramatize a Commedia dell'arte puppet play. Rákosi, in turn, was convinced that poetry and play could "expand the boundaries of life" "76 for these children, maybe even "relieve their souls of a great burden." The children also wrote and published their own poems (like the one at the start of this section) in their school newspaper, and 27 such poems were also published at

and directed it between 1937 and 1942. What especially intrigued him was the way Finland seemed to put resources on raising the cultural level of its agrarian population.

${ }^{74}$ Rákosi (1947), 418.

${ }^{75}$ Ibid.

${ }^{76}$ Rákosi (1947), 419. 
the end of Rákosi's essay. Many of these poems were quite clearly reflecting upon the personal experiences of trauma and loss.

So, while his focus was more pedagogical than therapeutic, Rákosi was nevertheless acknowledging that poetry might serve as a means of psychological release for the traumatized children. This was reminiscent of the general approach proposed a year later by Révész in her 1948 article maintaining that all therapy and readjustment should be based on "increasing self-awareness." In other words, the children should each be encouraged to find the different elements needed for mental recovery from within themselves. But because this process of self-reflection was such a difficult path to take for these very conflicted children-not least because adults rarely had any idea about what these "secret mental paths" were-the presence of professionals was crucial to "holding their hands as symbolic mothers." 77

Rákosi talked more openly about the therapeutic function of poetry in a newspaper article from $1948 .^{78}$ Understandably, many of his students had developed a state of mind that was "dark, strange, timid and distrustful"; almost all of his "sweet and unhappy children" had lost at least one of their parents in 1944-1945, and, after trying out many different methods, he felt he had failed to give them the comfort they needed. It was only when he introduced his "rhythm games" to the class that a completely new kind of psychological reality began to open up:

At the point when a small 9-year-old orphan presented her deepest sorrows in four simple lines, describing the longing for her dead mother and father, she also felt relieved. She became something else. These children's poems are indeed strange, incredibly complicated, psychological mysteries. ${ }^{79}$

Rákosi described his pedagogical experiment as being born from the helplessness he felt when faced with the mental suffering of these pupils.

\footnotetext{
${ }^{77}$ Révész (1948), 560-1.

${ }^{78}$ Zsoldos (1947), 9. Haladás ("Progress"), was a radical anti-fascist (but not communist) newspaper established in 1945.

${ }^{79}$ Zsoldos (1947), 9.
} 


\section{A ChILD's-Eye VIEW}

In the last part of this chapter, I look at narrative representations of everyday wartime traumas in childhood by focusing on a particularly interesting memoir and diary written by Margit Tolnainé Kassai in the last year of the war. Kassai (1909-2000) was a Jewish woman who played a significant role in nursing Jewish children in temporary homes run by the International Red Cross in Budapest under the German occupation, during the Arrow Cross reign of terror and siege. The memoir, beginning in 1944, contains over 200 pages, dedicated to her faraway husband, and written in a matter of months between early March and early May 1945. On the day of Budapest's "liberation" by the Red Army (11 February 1945), she also started to keep a diary, where she described everyday life and conditions under the Soviet occupation. ${ }^{80}$ Among many other things, Kassai's narrative portrays a number of children, which makes it an important document for studying their experiences. It also provides a fascinating hands-on view of what it might have been like to shelter children in such dangerous conditions. In what follows, I will look at how Kassai's "bottom up" narrative, and the interpretations of children it contains, possibly differed from the public discourse surrounding childhood in this era.

The memoir begins in April 1944, when Margit Kassai, an employee at the Hungarian General Credit Bank, gifted photographer and nonreligious Jew, had to leave her house in Buda following the German occupation (19 March) and move to an apartment building especially designated for Jews in the inner city of Pest. ${ }^{81}$ In this house, she lived together with many other families for a few months and organized day-care activities for the children there. However, after the Arrow Cross takeover (15 October), she found it too risky to stay in the house anymore, so she fled and stayed with friends for a couple of weeks, until managing to become a nurse for

\footnotetext{
${ }^{80}$ The original manuscript is kept in the Szabó Ervin Library in Budapest. The whole narrative (introductory letter, memoir and diary) has now been published: Margit Tolnainé Kassai, Óvoda az óvóbelyen - Feljegyzések a Szteblo-gyermekmentésről (Budapest: Magvető Kiadó, 2020). The book also includes a thorough scientific introduction by Gergely Kunt.

${ }^{81}$ The authorities of Budapest decided in April 1944 that all the Jews had to move to the so-called Yellow Star Houses. In comparison to other cities in the East-Central European region, this was a rather unusual kind of ghetto and particular to the Budapest Jews (and their children) during the Holocaust. See Ágnes Nagy, Harc a lakáshivatalban: Politikai átalakulás és mindennapi érdekérvényesités a fövárosban, 1945-1953 (Budapest: Korall, 2013), 80-90; Zsuzsanna Ozsvath, When the Danube Ran Red (New York: Syracuse University Press, 2010), 97-9.
} 
the International Red Cross with the help of Gábor Sztehlo, who was heading its child rescue program in Budapest at the time and looking for people to work in his previously mentioned Good Shepherd orphanages. As these shelters and their employees were (at least theoretically) under international protection, Kassai managed to survive both the Arrow Cross and Siege of Budapest, while taking care of the children she was also hiding with.

While Kassai's narrative is a potential source for many kinds of study, perhaps most obviously the life of Jews and others in Budapest in 1944-1945, ${ }^{82}$ the everyday life she spent with children must certainly be one of its defining themes. One can see clearly how children made a deep impression on Kassai. Nursing gave meaning to the everyday strugglesfor example, the dangerous trips for food and water, the lack of sleep and the terrible hygiene-thereby making them easier to bear. Ensuring that the children survived must have helped her build a sense of continuity for her own future too, as at many points in the narrative she admits that looking after the children and playing with them kept her sane amid the conflict of adults. ${ }^{83}$

At one point in the narrative, she illustrates these feelings with a small story called "Secrets of the Child's Heart." It takes place in a children's air raid shelter at some point towards the end of January 1945, when bombing and fighting were at their heaviest in Budapest. One day, however, when there was a relative lull in the violence, all the adults in the shelter went out into the courtyard to gather bricks from the rubble, and they built a protective wall to add protection. A few days later, while playfully chatting with the kids, she found herself asking them if only one nurse could look after them, who would it be? "Laughing, they looked at each other and answered right away that it would be either Aunt Margit (me) or Aunt Bozsi." The reason they gave for this, Kassai recounts, was because she and Bozsi were the adults who treated every child equally and without favoritism. It turned out that when the adults had gone out to gather bricks during the lull earlier that week, they had played a game about what to do if the courtyard suffered a direct hit, killing all the adults at once and

\footnotetext{
${ }^{82}$ For an overview of the many themes in Kassai's text, see Gergely Kunt, "Ironic Narrative Agency as a Method of Coping with Trauma in the Diary - Memoir of Margit K., a Female Holocaust Survivor," Hungarian Cultural Studies (e-Journal of the American Hungarian Educators Association) 7 (2014), https://doi.org/10.5195/ahea.2014.137

${ }^{83}$ Kassai (2020), 41.
} 
leaving just the kids in the shelter. Then they played a variation, with the assumption that "either Aunt Bozsi or Aunt Margit" was the sole adult survivor. During this game, they imagined how they would organize the house and cellar, who would share with whom in each room, what they would do with the ham that still was left and who would do the cooking. The only problem was knowing what to do with the unbearable baby they called "Wald." So, they then played another variation, where the baby was also killed with the adults (save for either "Bozsi" or "Margit" of course). As Kassai writes to her husband, it was simply quite instructive to see how the minds of these children worked..$^{84}$

The story is a fine example of the way Kassai generally wrote about the children - seeing them as active human beings rather than victims. She describes one 14-year-old “jeweler's assistant” from Józsefváros, for instance, as a "sharp-witted but lovable rogue" and "very good with his hands," in more ways than one: "one can't help forgiving his nimble fingers as they are great at fixing whatever goes wrong in the house too." 85 Then there was the 11-year-old son of a medical doctor, who had been forced to undergo plastic surgery to "rectify" his circumcision, and would often perform songs by Zoltán Kodály to the other kids. Then there was his cousin "Sutyi," who was constantly reading until eventually forced into the candlelit world of the basement. Some of the children, nevertheless, were clearly difficult, disorderly and messy; while some would bully other kids, others were refusing to eat, wetting their beds, or visibly miserable and clearly missing their parents.

But the latter sometimes developed their own strategies for dealing with the bullying-like "little Évike," a seven-year-old girl, who would often sing herself loudly to sleep in the dark.$^{86}$ She became especially close to a five-year-old boy called Palkó that Kassai wrote about more than once, probably because he was the first orphan she met. In these descriptions concerning Palkó, Kassai took stock of her overall relationship with the children, the feelings she attached to them and the challenges of keeping them calm in conditions of war and bombing. In doing so, though it is not explicit, a particular kind of "treatment ideology" seems to coalesce and take shape. At many times in the narrative, and particularly during the encounters with little Palkó, she confesses how difficult it was to maintain

\footnotetext{
${ }^{84}$ Ibid., 234-6.

${ }^{85}$ Ibid., 163.

${ }^{86}$ Ibid., 165, 259.
} 
"proper standards of care," by which she meant keeping the correct emotional distance between herself and the children-almost certainly referring to what was known as the "Loczy method" in Hungary. According to this method, it was fine that children were not always missing their mothers, but at the same time it was wrong if the children became too emotionally attached to the replacement mother figure. Kassai claimed that she gradually learned to "remain calm" when faced with children's mental suffering ("in the same way a nurse gets used to blood"), but as her notes reveal, from time to time she found this impossible. When Palkó got sick, for instance, she wrote about how bad it felt to have to leave him for a couple of days (when she was forced to make a trip), and how she was afraid of losing him. As the sallow, withdrawn boy sitting in the corner said to her one day: "it's very bad for me to be here, because all the people are strangers." When Kassai then asked him if he felt she was a stranger, the boy answered: "only a half-stranger, but I love my mother the most."

As Gergely Kunt points out, Kassai's text can be approached as a special kind of trauma narrative - an attempt to process and reflect upon personal traumas through writing. ${ }^{87}$ Kunt has studied the narrative strategies used by Kassai to construct meaningful experiences out of the traumatic events she faced. He convincingly suggests, for example, that Kassai's use of gentle irony and black humor was a coping mechanism to help her deal with stressful situations. ${ }^{88}$ Kunt also points out differences in the tone and style of writing between her memoir and diary: the emotional atmosphere in the diary being somewhat less hopeful. ${ }^{89}$ Kassai, herself, also shows a critical awareness of the "literary" qualities of her memoir when she writes in the introduction that she wishes she could have taken daily notes of her impressions and events until the very end of the siege, as she wanted to make "the whole thing more realistic and not so literary."

One interesting dimension of this source relates to the way Kassai presents herself in the memoir. For example, she refers to many dangerous and frightening situations, in which she felt fear and even despair, but at no point does she want to give an impression of herself as a victim. Although she is very honest about the many anxieties she felt, and shares with her

\footnotetext{
${ }^{87}$ Kunt (2014).

${ }^{88}$ Ibid., 31.

${ }^{89}$ See, for example, the entry from 22 February 1945, which deals with plundering Soviet soldiers; Kassai (2020), 288-9.

${ }^{90}$ Kassai (2020), 17.
} 
husband/reader even the most intimate physical problems (e.g., incontinence, menstrual issues and stomach troubles), it seems she also wants to convey how fearless she was. For instance, on one occasion when looking for water and candles, she saw some corpses "lying neatly next to one another [...] like a wagonload of goods waiting to be transported," and she describes how, "despite the thick snowfall," she felt like she was defying "the elements and a thousand dangers, just like the hero in a movie."

If we compare this with a diary entry from 19 February 1945, however, the emotional landscape is somewhat bleaker, as Kassai tries to describe the difficult job of getting children into Sztehlo's new children's home on the hills of Buda. Though the siege and the fighting were already over, after months of physical and mental hardships, the long journey up the hill (with heavy loads to carry) was almost the last straw. At this point, the reactions of a ten-year-old girl gave her the chance to witness a child's-eye view of death. Kassai describes how the girl, who was "usually very smart, cheerful and balanced" suddenly started crying uncontrollably and refused to go any further when she saw corpses at the hospital gate in front of them. Getting increasingly hysterical (also because the other adult was yelling at her), the girl desperately asked if there wasn't another route they could take. But, because this was out of the question, Kassai decided to shield the sobbing girl under her coat so she would not have to see anything. As they passed the bodies, Kassai describes how "the girl's whole body shook," but how when they finally got to the children's home, she "bravely opened her eyes."

\section{CONCLUSION}

At this point, we return to Jeffrey Alexander, mentioned so far only briefly in the introduction to this chapter. His social-constructionist approach to trauma is based on the argument that people conceptualize pain and suffering in terms of collective stories. In this respect, his social theory of trauma offers a particularly useful framework for studying how different kinds of violent events have been publicly constructed as traumatic by specific institutions and carrier groups (according to their particular interests). Furthermore, as social psychologist Gilad Hirschberger has pointed out, collective traumas are not just social constructions of suffering, but

${ }^{91}$ Ibid., 187-8. 
are often also used to build identities. ${ }^{92}$ In this chapter, I have shown that children's victimhood was one such construction in post-war Hungary. In the devastating aftermath of the war, it was brandished as a sociopolitical metaphor for envisioning a better society of the future - as in many other countries (from Poland to Japan). ${ }^{93}$

However, Alexander's research design and his source material might not be so suitable for analyzing the real-life experiences of people who have faced everyday hardships during and immediately after a conflict. In this chapter, I have therefore tried to show how rare sources, such as Margit Kassai's wartime memoir and diary, can provide access to very personal experiences, and an alternative way to approach histories of trauma. What would be particularly interesting would be to systematically juxtapose such private narratives of suffering with public constructions of children's victimhood-especially if the private narratives were written in close proximity to the traumatic events they describe, and the public constructions were used for political and professional purposes. As we have seen, Kassai did not characterize the children she was in contact with as passive victims but as active ones, in spite of their suffering. What is also intriguing in her narrative is the unembellished and pragmatic picture she builds up of her everyday practice of nursing and helping children in the war. From Kassai's diary we get an immediate sense of the process she is going through to make sense of the traumatic events she is experiencing.

As Tara Zahra and others have rightly pointed out, the family and nation were widely regarded as central sources of emotional healing and individual strength for European children after World War II. In Hungary, the rather visible role of "war-afflicted" children might also have made them a suitable vehicle for articulating broader social, moral, and political issues of collective guilt and perpetratorhood. At the same time, the dynamics of traumatic memory were generally characterized by political and social taboos which meant that certain particularly painful issues for people and their families were not addressed, such as the rapes committed by Soviet soldiers, veteran

\footnotetext{
${ }^{92}$ Gilad Hirschberger, "Collective Trauma and the Social Construction of Meaning," Frontiers in Psychology 9:1441 (2018), 1-14; Alexander (2012), 125.

${ }^{93} \mathrm{See}$, for example, Owen Griffiths, "Japanese Children and the Culture of Death, January-August 1945," in Children and War: A Historical Anthology, ed. by James Marten and Robert Coles (New York: New York University Press, 2002), 167-8; Bernini (2015), 242-58. Griffiths studies the "culture of death" and sacrifice that was fed to children and teenagers in Japan during the Pacific War. According to Griffiths, this might have disappeared after Japan lost the war, but it was replaced with a "culture of life." Boys might not have been encouraged to die in battle anymore and girls were no longer encouraged to preserve their purity by killing themselves; but, instead, the new generation had to study hard and be brave in building a new culture.
} 
traumas on the Eastern Front, and perhaps most notably the failure of Hungarian society to address the huge personal suffering of its Jewish citizens. For ideological and pragmatic reasons, the hegemonic Communist party did not want to differentiate between singular experiences of suffering, but, rather, treated all victimized groups as victims of "Fascism." 94

The countries of Central and Eastern Europe emerged from World War II in a radically new political constellation. In Hungary, this change was characterized by historic land reforms and a general shift to the left, which also manifested itself in new psychological and educational discourses. Most importantly, as Hungary was now firmly in the Soviet sphere of influence, the Communists increasingly determined the substance of politics and public discourse..$^{95}$ In this chapter, I have referred to the popularity of including the issue of childhood trauma in the discourse arguing for a collective and future-oriented education at this time. This is also apparent in the public attention received by Gaudiopolis - the leftist political atmosphere at the time certainly supported these kinds of ideas and institutions.

However, the idea that a (children's) collective can be a potential site of healing should not be assessed solely against this backdrop of socialist nationstate-building, but also in the context of contemporary child psychology, not to mention the general socioeconomic and physical conditions that prevailed. One could argue that the institution appeared the most rational solution not so much because of the need to educate future socialist citizens, but because it was seen as the best (science-based) way to help orphans and other mentally distressed children readjust to a society ravaged by years of war and occupation.

In this chapter, I have paid attention to a range of voices and actors who either publicly discussed children's traumas or encountered them in their everyday lives. Indeed, the sources show a multiplicity of responses to childhood trauma, from abstract and future-oriented policy-talk to teachers and psychologists promoting specific ways of healing such as offering them moments of joy, taking them on nature trips and exploring poetry with them

\footnotetext{
${ }^{94}$ Hungarian historians have only recently started to unravel the social and psychological significance of these multiple silences. For sexual violence during and after the war, see Andrea Pető, Elmondani az elmondhatatlant: A nemi eröszak története Magyarországon a II. Világháború alatt (Budapest: Jaffa, 2018); Gergely Kunt, Kipontozva: Nemi erőszak második világháborús naplókban (Budapest: Osiris, 2019). See also Gábor Gyáni, A Nation Divided by History and Memory: Hungary in the Twentieth Century and Beyond (New York: Routledge, 2021), 67-87.

${ }^{95}$ See, for example Ignác Romsics, Hungary in the Twentieth Century (Budapest: Corvina, 1999), 245-64; Judit Meszáros, "Effect of Dictatorial Regimes on the Psychoanalytic Movement in Hungary before and after World War II," in Psychoanalysis and Politics: Histories of Psychoanalysis under Conditions of Restricted Political Freedom, ed. by Joy Damousi and Mariano Ben Plotkin (Oxford: Oxford University Press, 2012), 79-111.
} 
in innovative ways. At the same time, we should keep in mind that while the postwar period did see an overall growth in child psychology, there were still many traumatized children who never got the chance to enter into a therapeutic relationship with a psychologist or progressive teacher, or to enjoy the warmth of an emotionally supportive institutional community. So, if we focus only on the role of psychology professionals, then we are ignoring the important role that many others played in helping children readjust - such as teachers, the civil society activists who were running different activities for children, and children's own communities. In the fledgling Socialist states of postwar Central and Eastern Europe, one way to approach children's readjustment was to actively engage them in a new future-oriented form of socialization, and perhaps there was also a "therapeutic" dimension to this. In postwar Hungary, for instance, the main ideological and political struggle "in the name of children" actually took place between the Hungarian Kinderfreunde movement, the Scouts, and the Communist Pioneers- the latter emerging victorious. ${ }^{96}$ In this respect, contexts other than strictly professional therapeutic relationships were possibly more crucial for children's postwar readjustment than we have previously assumed. It could thus be rewarding for historians and others in the field of trauma studies to focus on studying these relationships more thoroughly in the future.

\footnotetext{
${ }^{96}$ András Kiss, “Gyermeksors a második világháború után-1946,” Archívnet 9:1 (1999), https://www.archivnet.hu/hetkoznapok/gyermeksors_a_masodik_vilaghaboru_ utan_1946.html (last accessed 23 January 2021).
}

Open Access This chapter is licensed under the terms of the Creative Commons Attribution 4.0 International License (http://creativecommons.org/licenses/ by $/ 4.0 /$ ), which permits use, sharing, adaptation, distribution and reproduction in any medium or format, as long as you give appropriate credit to the original author(s) and the source, provide a link to the Creative Commons licence and indicate if changes were made.

The images or other third party material in this chapter are included in the chapter's Creative Commons licence, unless indicated otherwise in a credit line to the material. If material is not included in the chapter's Creative Commons licence and your intended use is not permitted by statutory regulation or exceeds the permitted use, you will need to obtain permission directly from the copyright holder. 